\title{
Metabolism of Rat Brain Mitochondria
}

\section{STUDIES ON THE POTASSIUM ION-STIMULATED OXIDATION OF PYRUVATE}

\author{
By W. J. NICKLAS,* J. B. CLARK† AND J. R. WILLIAMSON \\ Johnson Research Foundation, University of Pennsylvania, Philadelphia, Pa. 19104, U.S.A.
}

(Received 1 January 1971)

\begin{abstract}
1. Rat brain-cortex mitochondria were incubated in media containing 1,5 or $100 \mathrm{mM}-\mathrm{K}^{+}$in the presence of ADP, uncoupler (FCCP, carbonyl cyanide $p$-trifluoromethoxyphenylhydrazone) or valinomycin while metabolizing pyruvate and malate, or acetylcarnitine and malate or glutamate and malate as substrates. Both the uptake of oxygen and disappearance of substrate were measured under these conditions. 2. With pyruvate and malate as substrate in the presence of both $\mathrm{ADP}$ and valinomycin, both the uptake of oxygen and disappearance of pyruvate increased markedly on increasing the $\mathrm{K}^{+}$content of the incubation medium from 5 to $100 \mathrm{~mm}-\mathrm{K}^{+}$. However, in the presence of uncoupler (FCCP), although the oxygen uptake doubled little change was observed in the rate of disappearance of pyruvate on increasing the $\mathrm{K}^{+}$concentration. 3. Only small changes in uptake of substrate and oxygen were observed in the presence of ADP, uncoupler (FCCP) or valinomycin on increasing the $\mathrm{K}^{+}$concentration when acetylcarnitine + malate or glutamate + malate were used as substrates by brain mitochondria. 4. Further, increasing the $\mathrm{K}^{+}$concentration from 1 to $20 \mathrm{mM}$ when rat brain mitochondria were oxidizing a mixture of pyruvate and glutamate in the presence of malate and ADP caused a $30 \%$ increase in the respiration rate, $50 \%$ increase in the rate of disappearance of pyruvate and an $80 \%$ decrease in the rate of disappearance of glutamate. 5. Investigation of the redox state of the cytochromes and the nicotinamide nucleotides in various conditions with either pyruvate or acetylcarnitine as substrates suggested that the specific stimulation of metabolism of pyruvate by $\mathrm{K}^{+}$could not be explained by a general stimulation of the electron-transport system. 6. Low-amplitude high-energy swelling of rat brain mitochondria was investigated in both $\mathrm{Na}^{+}$- and $\mathrm{K}^{+}$-containing media. Swelling of brain mitochondria was much greater in the $\mathrm{Na}^{+}$-containing medium and in this medium, the addition of $\mathrm{Mg}^{2+}$ caused a partial reversal of swelling together with an $85 \%$ decrease in the rate of utilization of pyruvate. However, in the $\mathrm{K}^{+}$-containing medium, the addition of $\mathrm{Mg}^{2+}$, although also causing a reversal of swelling, did not affect the rate of disappearance of pyruvate. 7. Measurements of the ATP, NADH/NAD ${ }^{+}$and acetyl-CoA/CoA contents were made under various conditions and no evidence that $\mathrm{K}^{+}$concentrations affected these parameters was obtained. 8 . The results are discussed in relationship to the physiological significance of the stimulation of pyruvate metabolism by $\mathrm{K}^{+}$in rat brain mitochondria. It is proposed that $\mathrm{K}^{+}$ causes its effects by a direct stimulation of the pyruvate dehydrogenase complex.
\end{abstract}

It has been shown that the respiration of brain preparations can be increased to approach rates in vivo by changes in the cation concentration of the medium used to incubate these preparations. Ashford \& Dixon (1935), using rabbit brain-cortex

* Present address: Department of Neurology, College of Physicians and Surgeons of Columbia University, New York, N.Y. 10032, U.S.A.

$\dagger$ Present address: Department of Biochemistry, St Bartholomew's Hospital Medical College, University of London, Charterhouse Square, London EC1M 6BQ, U.K. slices, and Dickens \& Greville (1935), using rat brain-cortex slices, demonstrated that an increase in $\mathrm{K}^{+}$concentration in the medium increased the rates, of both respiration and aerobic glycolysis in these slices. The work of Kini \& Quastel (1959, 1960) with $\left[{ }^{14} \mathrm{C}\right]$ glucose and Berl, Nicklas \& Clarke $(1968,1970)$ with ${ }^{14} \mathrm{C}$-labelled amino acids suggested that $\mathrm{K}^{+}$increased the turnover of glucose in brain slices at the expense of the oxidation of other substrates, e.g. glutamate or acetate (Berl et al. 1968, 1970). Quastel concluded that $\mathrm{K}^{+}$accelerates 
the conversion of pyruvate into acetyl-CoA in brain slices (Kini \& Quastel, 1959; Quastel, 1962). Stimulation of respiration of brain mitochondria by $\mathrm{K}^{+}$has been reported by several laboratories (Utida \& Sugawara, 1963; Krall, Wagner \& Gozansky, 1964; Ozawa, Seta, Araki \& Handa, 1967; Clark \& Nicklas, 1970). However, the nature of the enhancement has been the subject of some controversy. Utida \& Sugawara (1963) and Krall et al. (1964) suggested that $\mathrm{K}^{+}$activates a $\mathrm{Na}^{+}, \mathrm{K}^{+}$-stimulated adenosine triphosphatase associated with their brain mitochondrial preparation. Ozawa et al. (1967) indicated that a brain mitochondrial adenosine triphosphatase was not responsible for the $\mathrm{K}^{+}$-stimulation and was probably a contamination by membrane fragments in the previous preparations. Further, it has been shown by enzyme-distribution studies on subcellular fractions of rat brain cortex that purified brain mitochondria exhibit very little $\mathrm{Na}^{+}, \mathrm{K}^{+}$stimulated adenosine triphosphatase activity (De Robertis, Rodriguez De Lores Arnaiz, Alberici, Butcher \& Sutherland, 1967). Several authors have concluded that $\mathrm{K}^{+}$exerted a direct stimulatory effect on the electron-transport system (Krall et al. 1964; Ozawa et al. 1967; Kimmich \& Rasmussen, 1967). However, Clark \& Nicklas (1970) measured the changes in the oxidoreduction states of the cytochromes in brain mitochondria oxidizing pyruvate in various $\mathrm{K}^{+}$-containing media and found that the increase in uptake of pyruvate was not consistent with a simple stimulation within the electron-transport system. The presence in brain of high concentrations of $\mathrm{K}^{+}(100 \mu \mathrm{mol} / \mathrm{g}$ wet wt. $)$ (Hanig \& Aprison, 1967) and the fact that electrical stimulation of slices mimics the effect of $\mathrm{K}^{+}$ prompted us to investigate this problem further. As aerobic glycolysis accounts for $80-90 \%$ of normal central-nervous-system metabolism (Elliott \& Wolfe, 1962), an investigation into the $\mathrm{K}^{+}$. stimulated uptake of pyruvate by brain mitochondria might be of significance in understanding the $\mathbf{K}^{+}$-stimulation of glycolysis.

In the present work comparative studies of the oxidation of pyruvate + malate, acetylcarnitine + malate and glutamate + malate have been carried out in the presence of various concentrations of $\mathrm{K}^{+}$ with a brain mitochondrial preparation known to be relatively free from synaptosomal and cytoplasmic contamination (Clark \& Nicklas, 1970). The results indicate that there are at least two phenomena associated with the stimulatory effect of $\mathrm{K}^{+}$on respiration. First, and quantitatively smaller, is a non-specific ionic or salt effect in which all substrates are oxidized more readily, which may be associated with swelling of the mitochondria. Secondly, and quantitatively much greater, is a specific $\mathrm{K}^{+}$-stimulation of oxidation of pyruvate.
The evidence suggests that this effect is localized at the level of the pyruvate dehydrogenase complex. Preliminary accounts of portions of the work have appeared elsewhere (Clark, 1970).

\section{METHODS}

Preparation of mitochondria. Male Holtzman rats (weight $160-180 \mathrm{~g}$ ) were used in all experiments. Mitochondria were prepared by the method of Clark \& Nicklas (1970).

Incubation conditions. Incubations were carried out in the following media : $1 \mathrm{mM}-\mathrm{K}^{+}$medium; this contained the following solutions at the quoted final concentrations: $225 \mathrm{mM}$-mannitol, $75 \mathrm{~mm}$-sucrose, $1 \mathrm{mM}-\mathrm{KCl}, 10 \mathrm{mM}$-tris phosphate, $10 \mathrm{~mm}$-tris chloride, $0.05 \mathrm{mM}$-EDTA; $5 \mathrm{mM}-\mathrm{K}^{+}$ medium, as $1 \mathrm{~mm} \cdot \mathrm{K}^{+}$medium except that $5 \mathrm{mM}-\mathrm{KCl}$ was present; $100 \mathrm{~mm}-\mathrm{K}^{+}$medium, $75 \mathrm{~mm}$-mannitol, $25 \mathrm{~mm}$ sucrose, $100 \mathrm{~mm}-\mathrm{KCl}, 10 \mathrm{~mm}$-tris phosphate, $10 \mathrm{mM}$-tris chloride, 0.05 mM-EDTA. In certain experiments no added univalent cations were present; this is referred to as the 'zero' medium. In other experiments $\mathrm{Na}^{+}$was used in place of $\mathrm{K}^{+}$. In all cases these media were adjusted to pH 7.4 with $2 \mathrm{M}$-tris base. Substrates used were normally the free acids neutralized to $\mathrm{pH} \mathrm{7.4}$ with tris base.

Assay techniques. Oxygen uptakes were measured polarographically, and uptakes of substrates and accumulations of metabolites were measured after extraction of the mitochondrial incubation media with $18 \%$ (w/v) $\mathrm{HClO}_{4}$, centrifugation at $16000 \mathrm{~g}$ for $5 \mathrm{~min}$ and subsequent neutralization to $\mathrm{pH} 5$ with $3 \mathrm{M}-\mathrm{K}_{2} \mathrm{CO}_{3}$ in $0.5 \mathrm{M}$ triethanolamine (Williamson \& Corkey, 1969; La Noue, Nicklas \& Williamson, 1970). Uptakes of pyruvate, glutamate and malate were measured spectrophotometrically and accumulations of citrate, aspartate and $\alpha$-oxoglutarate fluorimetrically. Acetylcarnitine metabolism was measured by determining by fluorimetry the carnitine produced (see Williamson \& Corkey, 1969). In certain cases samples were removed for the measurement of nicotinamide nucleotides and coenzyme A derivatives. In both cases they were extracted and subsequently assayed fluorimetrically by the methods of Williamson \& Corkey (1969).

Cytochrome measurements. To measure the oxidationreduction states of the cytochromes in different $\mathrm{K}^{+}$media, samples from incubation experiments were transferred to cells of path length $2 \mathrm{~mm}$, and rapidly frozen in liquid $\mathrm{N}_{2}$. Low-temperature spectra were obtained with a splitbeam scanning spectrophotometer, as described by Clark \& Nicklas (1970).

Swelling experiments. The extinction changes related to swelling of brain mitochondria were followed at $520 \mathrm{~nm}$ with a Hitachi 124 double-beam spectrophotometer (Azzone \& Azzi, 1966).

Chemicals. Ficoll was obtained from Pharmacia, Uppsala, Sweden, and purified by dialysis before use. Pyruvic acid was twice distilled under vacuum and stored at $2^{\circ} \mathrm{C}$. All other substrates were commercial preparations of the highest purity available. Enzymes and coenzymes used in the spectrophotometric and fluorimetric assays were purchased from Boehringer (Mannheim) Corp., New York, N.Y., U.S.A., or Sigma Chemical Co., St Louis, Mo., U.S.A. 


\section{RESULTS}

Effect of $\mathrm{K}^{+}$on oxidation of substrates. As previously shown (Clark \& Nicklas, 1970), raising the $\mathrm{K}^{+}$concentration from $5 \mathrm{~mm}$ to $100 \mathrm{~mm}$ in a sucrose + mannitol medium caused a stimulation of oxygen uptake by rat brain mitochondria. With pyruvate + malate as substrate the oxygen uptake in state 3 (Chance \& Williams, 1956) increased by 50\%, coupled with a similar increase in pyruvate consumption on increasing the $\mathrm{K}^{+}$concentration (Fig. 1a, Table 1). When rat brain mitochondria were uncoupled with FCCP* in the presence of pyruvate + malate, the oxygen uptakes in $5 \mathrm{~mm}$ and $100 \mathrm{~mm}-\mathrm{K}^{+}$-containing media were slightly greater than the corresponding rates obtained in state 3 for the same $\mathrm{K}^{+}$concentration (Table 1 ). However, the pyruvate uptakes were substantially decreased to rates approximately one-half or onethird those of the state 3 values (Fig. $1 b$, Table 1 ). In the uncoupled state therefore respiration is being supported by endogenous sources of substrate, possibly fatty acid in nature (see Clark \& Nicklas, 1970). In the presence of valinomycin, which is known to facilitate the transport of $\mathrm{K}^{+}$ into mitochondria (Moore \& Pressman, 1964), the oxygen uptake and disappearance of substrate approximately doubled with pyruvate + malate as

* Abbreviation: FCCP, carbonyl cyanide $p$-trifluoromethoxyphenylhydrazone. substrate when the $\mathrm{K}^{+}$concentration was raised (Table 1). However, little change under the same conditions was noted with acetylcarnitine + malate as substrate (Table 2). When the $\mathrm{K}^{+}$concentration was raised from 5 to $100 \mathrm{mM}$, no significant increase in uptake of oxygen or substrate was observed in the presence of ADP (state 3 ) when acetylcarnitine + malate or glutamate + malate were used as substrates (Table 2), nor did the uptake of substrate and oxygen change significantly from the state-3 rates when uncoupler was added to mitochondria oxidizing acetylcarnitine + malate (Table 2). In all the above cases, the rates of utilization of substrate were linear over the time.period studied (8-10 min; cf. Fig. 1).

Effect of malate. The apparent $K_{m}$ for pyruvate of these mitochondria was approx. $40 \mu \mathrm{M}$ and did not vary with malate or $\mathrm{K}^{+}$concentration. However, the $V_{\max }$. for oxidation of pyruvate did vary with $\mathrm{K}^{+}$concentration (see Table 1 ). In addition, at low $\mathrm{K}^{+}$concentrations (Table 1), the malate concentration also appeared to influence the maximal velocity of uptake of both pyruvate and oxygen. The concentration of malate required for halfmaximal disappearance of pyruvate (apparent $K_{\mathrm{a}}$ ) in $5 \mathrm{mM}-\mathrm{K}^{+}$and $100 \mathrm{~mm}-\mathrm{K}^{+}$was $1 \mathrm{mM}-$ and $0.5 \mathrm{mM}$ malate respectively. However, even at high malate concentrations $(5 \mathrm{mM})$ there was still a $35 \%$ increase in disappearance of pyruvate on increasing the $\mathrm{K}^{+}$ concentration (Table 1) from 5 to $100 \mathrm{~mm}$. It seems
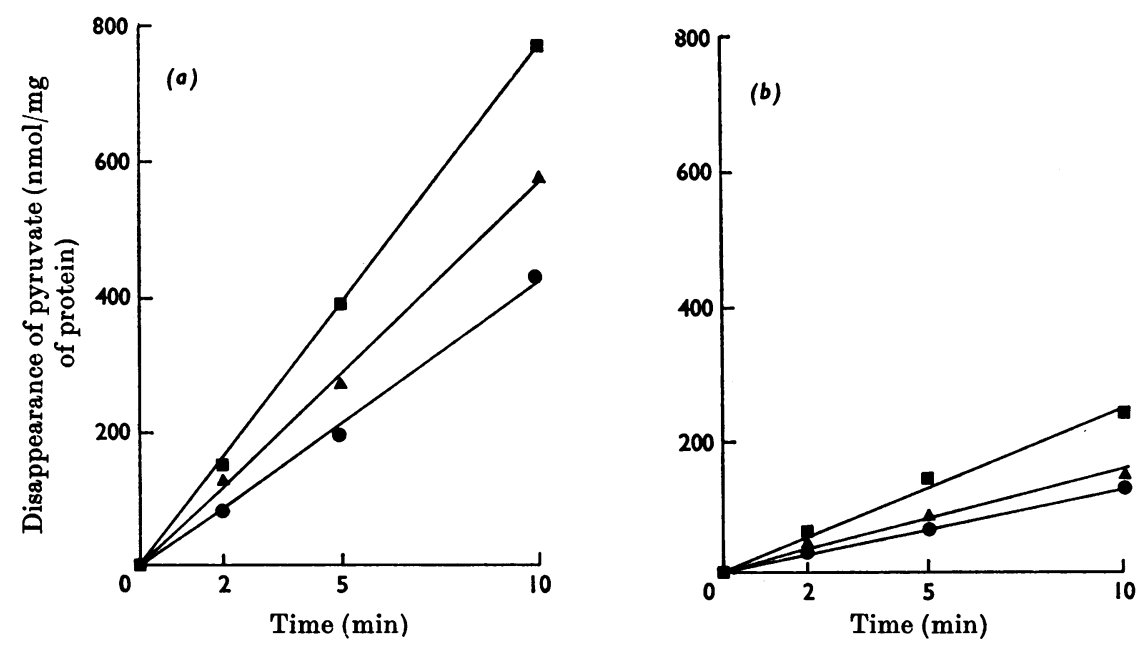

Fig. 1. Effect of $\mathrm{K}^{+}$on oxidation of pyruvate + malate, $(a)$ in state 3 or $(b)$ in the uncoupled state. Rat brain mitochondria $(0.7-0.8 \mathrm{mg}$ of protein $/ \mathrm{ml}$ of incubation medium) were incubated in oxygenated $1 \mathrm{~mm}(\bullet), 5 \mathrm{mM}$ $(\Delta)$ or $100 \mathrm{~mm}(\square)-\mathrm{K}^{+}$medium (see the Methods section) at $28^{\circ} \mathrm{C}$ in the presence of $1 \mathrm{~mm}$-malate +0.5 or $1 \mathrm{~mm}$ pyruvate, $10 \mathrm{mM}$-ADP $(a)$ or FCCP $(7 \mathrm{nmol} / \mathrm{mg}$ of protein); (b) (all final concentrations, $\mathrm{pH}$ adjusted to 7.4 with tris) in a final volume of $4.5 \mathrm{ml}$. A zero-time sample $(0.8 \mathrm{ml})$ was taken before the addition of the mitochondria and $1 \mathrm{ml}$ samples taken at 2,5 and $8 \mathrm{~min}$ during the incubation. The samples were processed and assayed as in the Methods section. 
Table 1. Effect of $\mathrm{K}^{+}$on utilization of pyruvate and malate and accumulation of citrate by rat brain mitochondria

Rat brain mitochondria ( $1 \mathrm{mg}$ of protein $/ \mathrm{ml}$ ) were incubated at $28^{\circ} \mathrm{C}$ in a sucrose-mannitol medium containing 1, 5 or $100 \mathrm{~mm}-\mathrm{K}^{+}$(see the Methods section). The initial concentration of pyruvate was $0.5-1 \mathrm{~mm}$ and that of malate 1 or 5mM. The respiration was stimulated by the presence of $10 \mathrm{mM}$-ADP or FCCP $(7 \mathrm{nmol} / \mathrm{mg}$ of protein) or valinomycin ( $7 \mathrm{ng} / \mathrm{mg}$ of protein). In each case the medium was oxygenated and the reaction was started by the addition of mitochondria. Samples were taken at various time-intervals after the initiation of the reaction and treated as described in Fig. 1. In all cases the rates of consumption of substrate or accumulation of citrate were linear, and the results represent the linear rate over the first $10 \mathrm{~min}$ (see Fig. 1). Oxygen uptakes were measured under similar conditions.

\begin{tabular}{|c|c|c|c|c|c|c|}
\hline \multicolumn{3}{|c|}{ Conditions } & \multicolumn{3}{|c|}{ Rate (nmol/min per mg, of protein) } & \multirow[b]{2}{*}{$\begin{array}{c}\text { Uptake of oxygen } \\
\text { (ng-atoms/min } \\
\text { per mg of protein) }\end{array}$} \\
\hline Stimulation & $\begin{array}{c}\mathbf{K}^{+} \\
\text {added } \\
(\mathbf{m M} \mathbf{M})\end{array}$ & $\begin{array}{l}\text { Malate } \\
\text { added } \\
(\mathrm{mM})\end{array}$ & $\begin{array}{c}\text { Disappearance of } \\
\text { pyruvate }\end{array}$ & $\begin{array}{c}\text { Disappearance of } \\
\text { malate }\end{array}$ & $\begin{array}{c}\text { Accumulation of } \\
\text { citrate }\end{array}$ & \\
\hline$+\mathbf{A D P}$ & $\begin{array}{r}1 \\
5 \\
100\end{array}$ & $\begin{array}{l}1 \\
1 \\
1\end{array}$ & $\begin{array}{l}\mathbf{4 2} \\
\mathbf{5 7} \\
\mathbf{7 9}\end{array}$ & $\begin{array}{l}48 \\
53 \\
64\end{array}$ & $\begin{array}{l}5 \\
5 \\
4.5\end{array}$ & $\begin{array}{r}84 \\
94 \\
172\end{array}$ \\
\hline$+\mathbf{A D P}$ & $\begin{array}{r}1 \\
5 \\
100\end{array}$ & $\begin{array}{l}\mathbf{5} \\
\mathbf{5} \\
\mathbf{5}\end{array}$ & $\begin{array}{l}\mathbf{5 5} \\
\mathbf{5 9} \\
\mathbf{7 4}\end{array}$ & - & $\begin{array}{r}10 \\
9 \\
9\end{array}$ & $\begin{array}{l}106 \\
121 \\
186\end{array}$ \\
\hline$+\mathbf{F C C P}$ & $\begin{array}{r}1 \\
5 \\
100\end{array}$ & $\begin{array}{l}1 \\
1 \\
1\end{array}$ & $\begin{array}{l}14 \\
12 \\
26\end{array}$ & $\begin{array}{r}4 \\
31 \\
38\end{array}$ & $\begin{array}{l}5.5 \\
8 \\
10\end{array}$ & $\begin{array}{l}101 \\
121 \\
201\end{array}$ \\
\hline$+\mathrm{FCCP}$ & $\begin{array}{r}1 \\
5 \\
100\end{array}$ & $\begin{array}{l}\mathbf{5} \\
\mathbf{5} \\
\mathbf{5}\end{array}$ & $\begin{array}{l}24 \\
28 \\
22\end{array}$ & - & $\begin{array}{l}11 \\
10 \\
13\end{array}$ & $\begin{array}{l}115 \\
160 \\
205\end{array}$ \\
\hline +Valinomycin & $\begin{array}{r}1 \\
5 \\
100\end{array}$ & $\begin{array}{l}1 \\
1 \\
1\end{array}$ & $\begin{array}{l}17 \\
27 \\
46\end{array}$ & $\begin{array}{l}22 \\
14 \\
52\end{array}$ & $\begin{array}{l}12 \\
12 \\
11\end{array}$ & $\begin{array}{r}60 \\
102 \\
193\end{array}$ \\
\hline +Valinomycin & $\begin{array}{r}1 \\
5 \\
100\end{array}$ & $\begin{array}{l}\mathbf{5} \\
\mathbf{5} \\
\mathbf{5}\end{array}$ & $\begin{array}{r}9 \\
23 \\
44\end{array}$ & - & $\begin{array}{l}11 \\
14 \\
13\end{array}$ & $\begin{array}{r}88 \\
109 \\
183\end{array}$ \\
\hline
\end{tabular}

Table 2. Effect of $\mathrm{K}^{+}$on utilization of acetylcarnitine + malate and glutamate + malate by rat brain mitochondria

Rat brain mitochondria ( $1 \mathrm{mg}$ of protein $/ \mathrm{ml}$ ) were incubated at $28^{\circ} \mathrm{C}$ in a sucrose-mannitol medium containing 5 or $100 \mathrm{~mm}-\mathrm{K}^{+}$(see the Methods section). The substrates present were 12 mm-acetylcarnitine $+5 \mathrm{~mm}$ malate or $2.5 \mathrm{mM}$-glutamate $+5 \mathrm{~mm}$-malate. The respiration was stimulated by the addition of $10 \mathrm{mM}$-ADP or FCCP $(7 \mathrm{nmol} / \mathrm{mg}$ of protein) or valinomycin $(7 \mathrm{ng} / \mathrm{mg}$ of protein). Acetylcarnitine utilization was estimated by measuring the carnitine produced and glutamate utilization by glutamate disappearance (see the Methods section). All other conditions and procedures were as described in Table 1 and Fig. 1 . In all cases the rates of substrate consumption were linear, and the results represent the linear rate over the first $10 \mathrm{~min}$ (see Fig. 1). Oxygen uptakes were measured under similar conditions polarographically.

\begin{tabular}{|c|c|c|c|c|c|}
\hline & & Oxidation o & cetylcarnitine & Oxidation & glutamate \\
\hline Stimulation & $\begin{array}{c}\mathbf{K}^{+} \\
\text {added } \\
(\mathbf{m M})\end{array}$ & $\begin{array}{l}\text { Disappearance } \\
\text { of substrate } \\
\text { (nmol/min per } \mathrm{mg} \\
\text { of protein) }\end{array}$ & $\begin{array}{c}\text { Uptake of } \mathrm{O}_{2} \\
\text { (ng-atoms/min per } \\
\text { mg of protein) }\end{array}$ & $\begin{array}{l}\text { Disappearance } \\
\text { of substrate } \\
\text { (nmol/min per } \mathrm{mg} \\
\text { of protein) }\end{array}$ & $\begin{array}{c}\text { Uptake of } \mathrm{O}_{2} \\
\text { (ng-atoms/min per } \\
\text { mg of protein) }\end{array}$ \\
\hline$+\mathbf{A D P}$ & $\begin{array}{r}5 \\
100\end{array}$ & $\begin{array}{l}14 \\
12\end{array}$ & $\begin{array}{l}63 \\
60\end{array}$ & $\begin{array}{l}\mathbf{7 0} \\
\mathbf{7 4}\end{array}$ & $\begin{array}{l}71 \\
92\end{array}$ \\
\hline$+\mathbf{F C C P}$ & $\begin{array}{r}5 \\
100\end{array}$ & $\begin{array}{l}13 \\
11\end{array}$ & $\begin{array}{l}57 \\
67\end{array}$ & - & - \\
\hline +Valinomycin & $\begin{array}{r}5 \\
100\end{array}$ & $\begin{array}{l}12 \\
12\end{array}$ & $\begin{array}{l}57 \\
60\end{array}$ & - & - \\
\hline
\end{tabular}


unlikely that the external malate concentration was limiting oxidation of pyruvate in any one of the above cases, for two reasons. First, with the 5 mM-malate incubations this concentration of malate is greatly in excess of the apparent $K_{\mathrm{a}}$ of malate for oxidation of pyruvate (1 mM). Secondly, in the presence of both $1 \mathrm{~mm}$ - and $5 \mathrm{~mm}$-malate, the rates of uptake of both pyruvate and malate were linear, despite the fact that the rate of uptake of malate ( $50 \mathrm{nmol} / \mathrm{min}$ per $\mathrm{mg}$ of protein) for the $1 \mathrm{mM}$ malate incubation (Table 1) would have caused a decrease in malate concentration to a value approaching the $K_{\mathrm{a}}$ for malate, $0.5 \mathrm{~mm}$. Thus, had malate been rate-limiting, a change to non-linear kinetics of pyruvate utilization would have been expected. It would seem therefore that $\mathrm{K}^{+}$has an effect other than simply facilitating entry of malate.

Increasing the malate concentration from 1 to $5 \mathrm{~mm}$ also caused an increase in accumulation of citrate by a factor of 2. This did not appear to be $\mathrm{K}^{+}$-dependent, nor was it changed by increase in utilization of pyruvate. These results are therefore consistent with the presence of a malate-dependent citrate permease in rat brain mitochondria, as suggested by Clark \& Nicklas (1970).

To examine whether $\mathrm{K}^{+}$could specifically activate pyruvate oxidation even in the presence of an alternative substrate, e.g. glutamate, the effects of $\mathrm{K}^{+}$on the metabolism of a pyruvate + glutamate + malate mixture were investigated. When the $\mathbf{K}^{+}$ concentration was increased from 1 to $20 \mathrm{~mm}$, the respiration in state 3 increased by $30 \%$ from 84 to $109 \mathrm{ng}$-atoms of oxygen/min per $\mathrm{mg}$ of protein (Fig. 2a). Concurrently, the uptake of pyruvate increased by $50 \%$ (Fig. $2 b$ ) from 32 to $47 \mathrm{nmol} / \mathrm{min}$ per $\mathrm{mg}$ of protein whereas production of aspartate, which is a measure of glutamate oxidation in these mitochondria (J. B. Clark \& W. J. Nicklas, unpublished work: Balazs, 1965), was decreased by a factor of 5 (Fig. $2 c$ ) from 46 to $9 \mathrm{nmol} / \mathrm{min}$ per $\mathrm{mg}$ of protein. Thus, the increase from $1 \mathrm{~mm}$ - to $20 \mathrm{~mm}-\mathrm{K}^{+}$ caused a switch from a state where almost equal quantities of pyruvate and glutamate were being oxidized to one where almost $90 \%$ of the substrate being oxidized was pyruvate.

Effect of $\mathrm{K}^{+}$on the cytochrome system. The relative oxidoreduction states of the cytochromes in the presence (state 3) and absence (state 4) of ADP in low-and high- $\mathrm{K}^{+}$media (together with values of the $\mathrm{NAD}^{+} / \mathrm{NADH}$ ratio calculated from Table 3 and the appropriate uptakes of oxygen and substrate taken from Tables 1 and 2) have been plotted in such a fashion that changes in the oxidoreduction states of the electron-transport carriers are related to changes in the rate of utilization of substrate and oxygen (i.e. a crossover plot). With both pyruvate + malate and acetylcarnitine + malate as substrates, the state 4 to state 3 transition in both low - and high. (a)
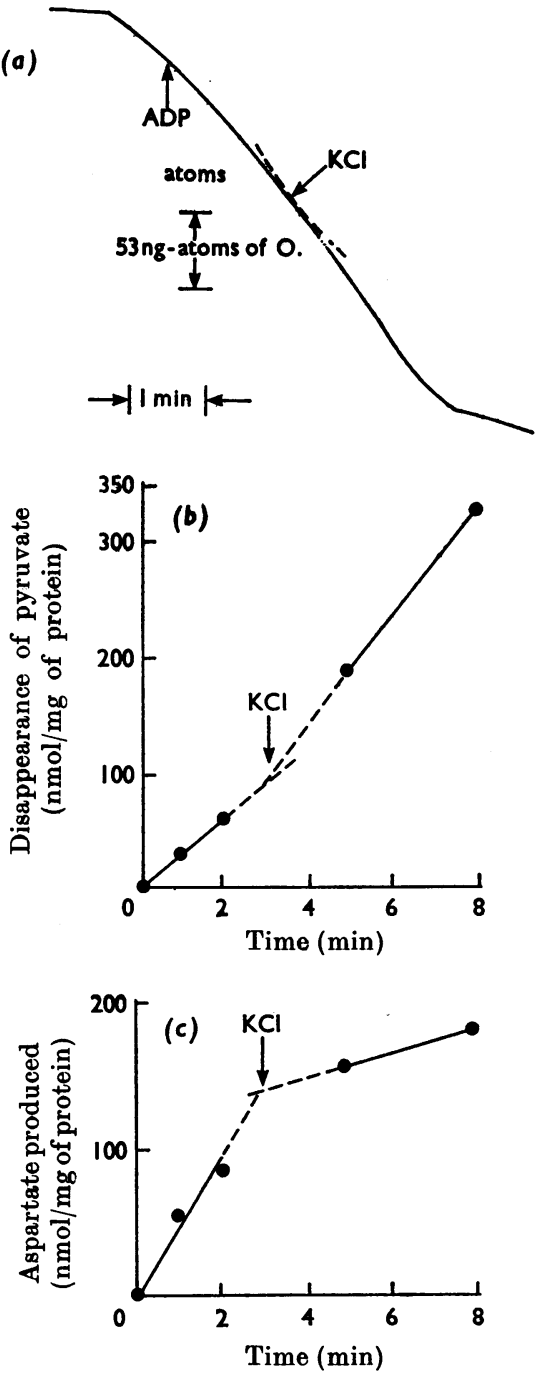

Fig. 2. Effect of $\mathrm{K}^{+}$on the oxidation of a mixture of pyruvate and glutamate + malate by rat brain mitochondria. (a) Effect of $\mathrm{K}^{+}$on oxygen uptake by brain mitochondria oxidizing a mixture of glutamate and pyruvate. Mitochondria $\left(0.8 \mathrm{mg}\right.$ of protein $/ \mathrm{ml}$ ) were inoubated in $1 \mathrm{~mm}-\mathrm{K}^{+}$ medium (see the Methods section) containing 5 mM-malate, $2.5 \mathrm{~mm}$-pyruvate and $2 \mathrm{~mm}$-glutamate in a final volume of $1 \mathrm{ml}$. State 3 was initiated with $1 \mathrm{~mm}$-ADP and subsequently the $\mathrm{K}^{+}$concentration was increased to $20 \mathrm{mM}$ by addition of $\mathrm{KCl}$. The rate of $\mathrm{O}_{2}$ uptake before the addition of $\mathrm{KCl}$ was $84 \mathrm{ng}$-atoms/min per $\mathrm{mg}$ of protein and afterwards 109. (b) and (c), Effect of $\mathrm{K}^{+}$on disappearance of pyruvate $(b)$ and formation of aspartate $(c)$ in brain mitochondria oxidizing a mixture of pyruvate and glutamate in state 3. Incubation conditions were as in (a). The rates of disappearance of pyruvate before and after addition of $\mathrm{KCl}$ were 32 and $47 \mathrm{nmol} / \mathrm{min}$ per $\mathrm{mg}$ of protein respectively. The rates of production of aspartate before and after addition of $\mathrm{KCl}$ was 46 and $9 \mathrm{nmol} / \mathrm{min}$ per $\mathrm{mg}$ of protein. 
$\mathrm{K}^{+}$media have been inserted for reference (Figs. 3 and 4). In all the state 4 to state 3 transitions similar trends were apparent, particularly with reference to cytochrome $b$, which was always more oxidized in state 3 than in state 4 . When the results with pyruvate or acetylcarnitine as substrates were plotted such that the $5 \mathrm{~mm}-\mathrm{K}^{+}$medium was compared with the $150 \mathrm{~mm}-\mathrm{K}^{+}$medium, it was apparent that $\mathrm{K}^{+}$was interacting at all three phosphorylation sites, which may be attributed to a generalized ionic or salt effect occurring at the level of the electrontransport system (Kimmich \& Rasmussen, 1967), or may be associated with a non-specific swelling. However, with pyruvate + malate as substrate, cytochrome $b$ was considerably more reduced in the $150 \mathrm{~mm}^{-\mathrm{K}^{+}}$medium than in the $5 \mathrm{~mm}-\mathrm{K}^{+}$medium, both in the presence and absence of ADP, whereas with acetylcarnitine + malate as substrate, the

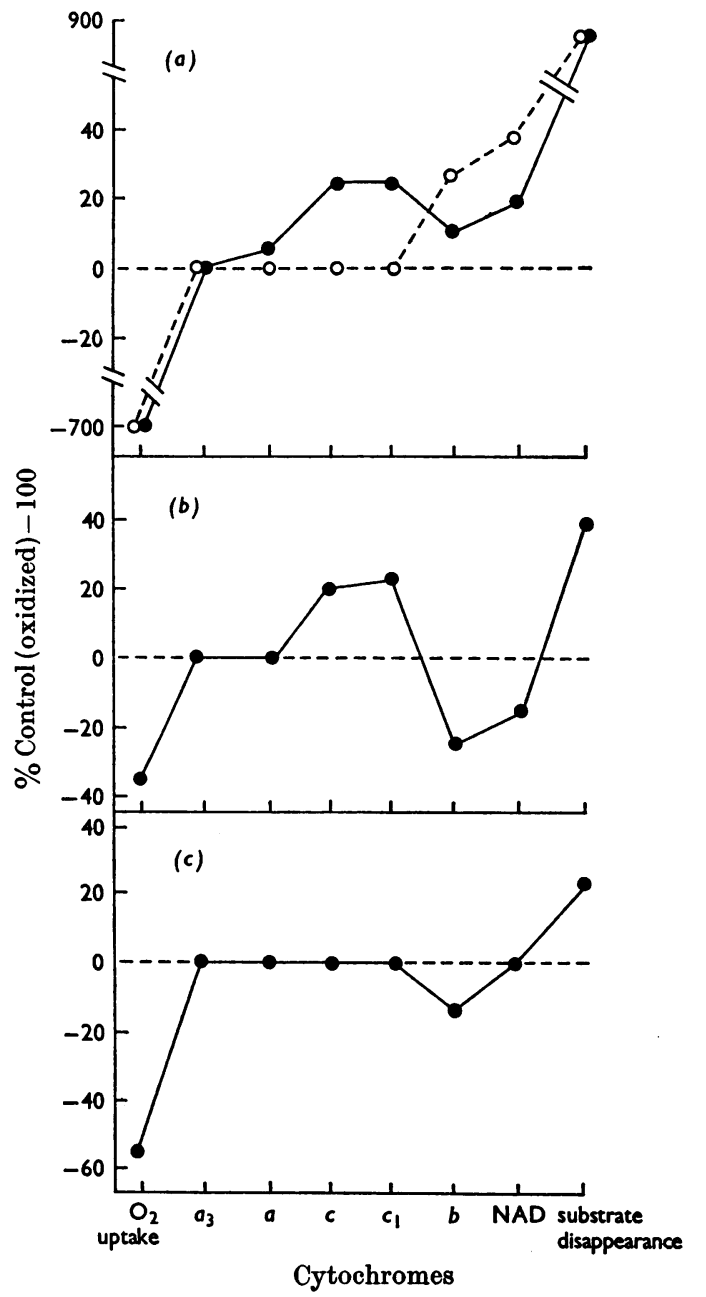

situation was reversed, with the cytochrome $b$ more oxidized in the high- $\mathrm{K}^{+}$medium than in the low-K $\mathrm{K}^{+}$medium (cf. state 4 -state 3 transition). This suggests that $\mathbf{K}^{+}$specifically affects pyruvate oxidation and that this must occur at a site remote from the electron-transport system itself.

Control of pyruvate dehydrogenase. The pyruvate dehydrogenase complex isolated from a number of tissues is known to be inhibited by $\mathrm{NADH}$ and acetyl-CoA (Garland \& Randle, 1964; Hansen \& Henning, 1966). Table 3 shows that when the lowand high- $\mathrm{K}^{+}$media were compared, no significant change in NAD reduction occurred on the addition of malate alone either with or without ADP, although the NADP was slightly more oxidized in the high- $\mathrm{K}^{+}$medium. This suggested that utilization of endogenous substrate was not affected by increased $\mathrm{K}^{+}$. In state 4 , when malate + pyruvate or malate + acetylcarnitine was added, the NAD was approximately $10 \%$ more reduced in the high-K $\mathrm{K}^{+}$ medium than in the low- $\mathrm{K}^{+}$medium, whereas with

Fig. 3. Effect of $\mathrm{K}^{+}$on the redox state of the electroncarrier system in brain mitochondria oxidizing pyruvate + malate in state 3 or state 4. Brain mitochondria were incubated with $1 \mathrm{~mm}$-pyruvate- $5 \mathrm{~mm}$ malate in either state 3 or state 4 (presence or absence of ADP) as described previously (Clark \& Nicklas, 1970). Steady-state concentrations of cytochromes were calculated from $77^{\circ} \mathrm{K}$ spectra obtained by 'trapped steady-state' techniques (Clark \& Nicklas, 1970). Concentrations of nicotinamide nucleotides were calculated from Table 3, and substrate flux and oxygen uptake from Fig. 1 and previous work (Clark \& Nicklas, 1970). The results are plotted in the following way; the respiratory-chain carriers and rates of $\mathrm{O}_{2}$ and substrate utilization are indicated on the abscissa, the ordinate shows changes in these parameters between different states. The scale of the ordinate for the electron carriers was plotted as a change in the percentage of oxidized carrier in a given state as compared with a control state, i.e.

$$
\frac{\left(\frac{\text { oxidized carrier }}{\text { total carrier }}\right)}{\left(\frac{\text { expt. }}{\text { total carrier }}\right)} \times 100-100
$$

In the case of oxygen uptake and substrate disappearance the ordinate represents the percentage increase in substrate disappearance (i.e. oxidation) and percentage increase in oxygen consumption (i.e. reduction). In general a positive trend indicates increased oxidation, a negative trend an increased reduction. The control state in each case was either state 4 (in the state 4-state 3 transition) or $5 \mathrm{~mm}-\mathrm{K}^{+}$medium (in the 5-150 mM-K $\mathrm{K}^{+}$ transition in state 3 or 4). (a) State 4-state 3 transition; O, $150 \mathrm{~mm}-\mathrm{K}^{+}, \bullet, 5 \mathrm{~mm}-\mathrm{K}^{+}$; (b) state 4, 5-150 mM-K $\mathrm{K}^{+}$ transition; (c) state $3,5-150 \mathrm{~mm}-\mathrm{K}^{+}$transition. 


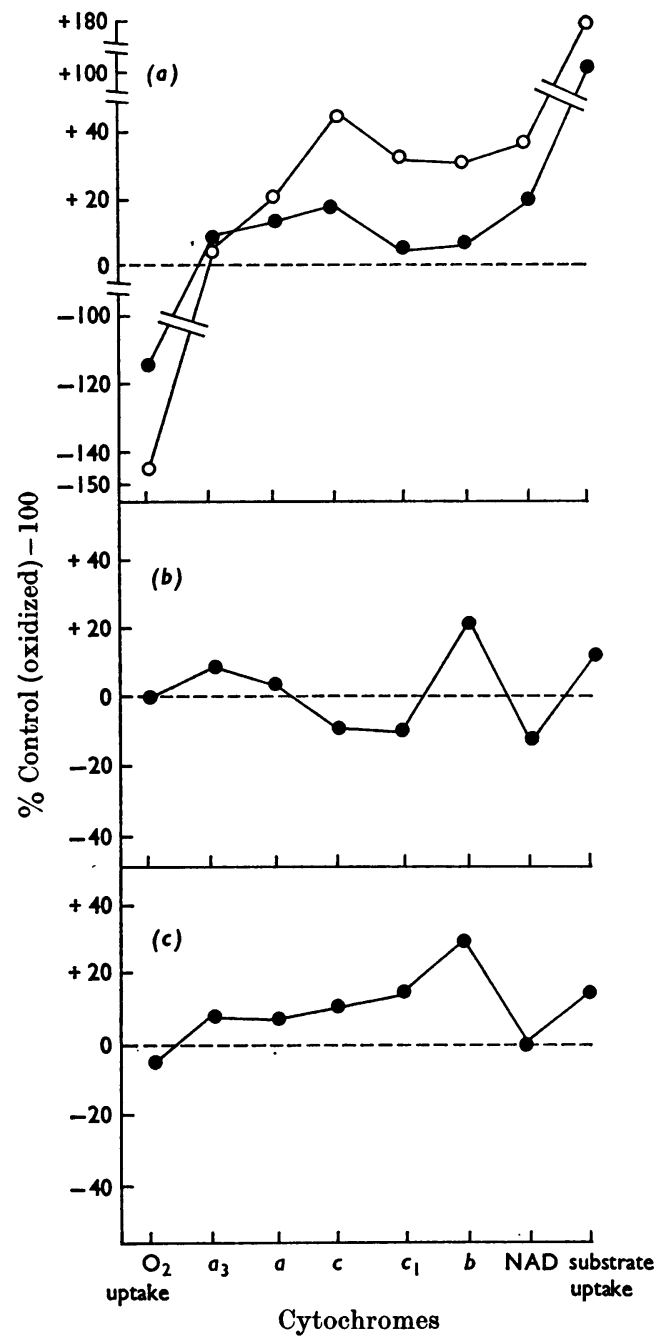

Fig. 4. Effect of $\mathrm{K}^{+}$on the redox state of the electroncarrier system in brain mitochondria oxidizing acetylcarnitine + malate in state 3 or state 4. Mitochondria were incubated in the presence of $12 \mathrm{~mm}$-acetylcarnitine+ 5 mM-malate in state 3 or state 4 as described for Fig. 3. Subsequent determinations and calculations were as described for Fig. 3. Symbols and abbreviations are as for Fig. 3.

glutamate + malate there was little difference in reduction of NAD between the two media. The NADP, however, became more oxidized in the high$\mathrm{K}^{+}$medium with pyruvate or glutamate, but remained unchanged with acetylcarnitine. In state 3, no differences were observed when the NAD or NADP oxidoreduction states with all three substrates in the low- and high- $\mathrm{K}^{+}$medium were compared. In these cases, only $10 \%$ or less of the NAD was reduced and $75-85 \%$ of the NADP was reduced. Two further general points are notable with respect to the NAD/NADP states in these mitochondria. First, the relatively small amount of NAD reduction in the absence of ADP (20-40\%) compared with other mitochondria (La Noue et al. 1970) and secondly, the observation that in the presence of $5 \mu \mathrm{M}$-rotenone only about two-thirds of the total NAD present was reduced and about 85$90 \%$ of the total NADP.

A second parameter that could control the rate of pyruvate oxidation is the availability of CoA for acetyl-CoA formation, or alternatively, the ability of acetyl-CoA to form citrate and hence release CoA for further use. In Table 4 the percentage changes in free CoA, acetyl-CoA and long-chain acyl-CoA derivatives are reported for a variety of conditions. The total $\mathrm{CoA}$ concentration $[1.02 \pm$ 0.01 (s.E.M., $n=22$ ) $\mathrm{nmol} / \mathrm{mg}$ of protein] is low compared with other mitochondria [rat heart, 2.5-3.0 nmol/mg of protein (K. La Noue, unpublished work); rat liver, 2.5-3.5 $\mathrm{nmol} / \mathrm{mg}$ of protein (Williamson, Fukami, Peterson, Rostand \& Scholz, 1969)] as was the steady-state concentration of acetyl-CoA formed from the free CoA in state 3 (approx. 10\% in brain mitochondria but $90 \%$ in heart mitochondria; Williamson et al. 1969). In state 3 with pyruvate + malate as substrate, a slight increase in acetyl-CoA occurred when the high-K ${ }^{+}$ medium was compared with the low-K $\mathrm{K}^{+}$medium. There were no significant changes in the concentration of free CoA nor in the long-chain fatty acyl-CoA derivatives. Similarly in state 4, an increase in the $\mathrm{K}^{+}$concentration caused an approximate doubling of the acetyl-CoA concentration coupled with a complementary fall in the free CoA pool. There was little change in the amount of long-chain acylCoA. In the uncoupled state, in contrast with state 3 or state 4, there was no increase in either acetyl-CoA or free CoA on increasing the $\mathrm{K}^{+}$concentration. However, with acetylcarnitine + malate as substrate in state 3 there appeared to be a slight decrease in acetyl-CoA and long-chain acyl-CoA derivatives in the $100 \mathrm{~mm}-\mathrm{K}^{+}$medium compared with the $5 \mathrm{~mm}-\mathrm{K}^{+}$medium. Since there was a trend in these experiments of increased acetyl-CoA concentrations in the high-K $\mathrm{K}^{+}$medium, this suggests that it may be the step pyruvate to acetyl-CoA that limits pyruvate oxidation.

Effect of $\mathrm{K}^{+}$on $A T P$ concentrations. Varying the $\mathrm{K}^{+}$concentration had no effect on ATP concentrations in mitochondria respiring in state 4 or after stimulation of respiration by uncoupler (FCCP) or an ionophore (valinomycin) (Table 5). However, the ATP concentrations were decreased from the state 4 values, as would be expected, by approx. $25 \%$ with FCCP and by $30 \%$ with valinomycin. For reference purposes, the total adenine nucleotide concentration in these brain mitochondria is 
Table 3. State of nicotinamide nucleotide reduction in rat brain mitochondria

Rat brain mitochondria were incubated at $28^{\circ} \mathrm{C}$ in media containing 5 or $100 \mathrm{~mm}-\mathrm{K}^{+}$(see the Methods section). Mitochondrial protein $(10 \mathrm{mg})$ was suspended in an initial volume of $3.0 \mathrm{ml}$ of medium, and samples (0.5 ml) were taken for analysis of nicotinamide nucleotides after various additions (Clark \& Nicklas, 1970). Total NAD was $2.48 \mathrm{nmol} / \mathrm{mg}$ of protein, and total NADP, $0.52 \mathrm{nmol} / \mathrm{mg}$ of protein.

\begin{tabular}{|c|c|c|c|c|}
\hline \multirow[b]{3}{*}{ Additions } & \multicolumn{4}{|c|}{ Reduction (\%) } \\
\hline & \multicolumn{2}{|c|}{$5 \mathrm{mM}-\mathrm{K}^{+}$medium } & \multicolumn{2}{|c|}{$100 \mathrm{mM}^{-\mathrm{K}^{+}}$medium } \\
\hline & NAD & NADP & NAD & NADP \\
\hline $\begin{array}{l}\text { None } \\
2.5 \mathrm{~mm} \text {-Malate } \\
2.5 \mathrm{~mm} \text {-Malate }+0.2 \mathrm{~mm}-\mathrm{ADP}\end{array}$ & $\begin{array}{l}3.2 \\
4.0 \\
4.7\end{array}$ & $\begin{array}{l}3.1 \\
85 \\
83\end{array}$ & $\begin{array}{l}1.2 \\
4.0 \\
3.6\end{array}$ & $\begin{array}{l}31 \\
75 \\
75\end{array}$ \\
\hline $\begin{array}{l}\text { State } 4 \text { (-ADP) } \\
2.5 \mathrm{~mm} \text {-Malate+ } 1 \mathrm{~mm} \text {-pyruvate } \\
2 \mathrm{~mm} \text {-Malate }+13 \mathrm{~mm} \text {-acetylcarnitine } \\
2 \mathrm{mM} \cdot \text {-Malate }+2.5 \mathrm{~mm} \text {-glutamate }\end{array}$ & $\begin{array}{l}27 \\
20 \\
38\end{array}$ & $\begin{array}{r}>90 \\
77 \\
>90\end{array}$ & $\begin{array}{l}37 \\
31 \\
35\end{array}$ & $\begin{array}{l}75 \\
80 \\
84\end{array}$ \\
\hline $\begin{array}{l}\text { State } 3 \text { (+ADP) } \\
2.5 \mathrm{~mm} \text {-Malate + } 1 \mathrm{~mm} \text {-pyruvate }+1.4 \mathrm{~mm}-\mathrm{ADP} \\
2 \mathrm{~mm} \text {-Malate }+13 \mathrm{~mm} \text {-acetylcarnitine }+0.7 \mathrm{mM}-\mathrm{ADP} \\
2 \mathrm{mM}-\text { Malate }+2.4 \mathrm{~mm} \text {-glutamate }+1.4 \mathrm{mM}-\mathrm{ADP}\end{array}$ & $\begin{array}{l}10 \\
4.6 \\
11\end{array}$ & $\begin{array}{l}86 \\
81 \\
86\end{array}$ & $\begin{array}{l}11 \\
4.6 \\
10\end{array}$ & $\begin{array}{l}76 \\
77 \\
86\end{array}$ \\
\hline $\begin{array}{l}+5 \mu \mathrm{M} \text {-Rotenone } \\
\quad 1 \mathrm{~mm} \text {-Pyruvate }+2.5 \mathrm{mM} \text {-malate } \\
13 \mathrm{~mm} \text {-Acetylcarnitine }+2 \mathrm{~mm} \text {-malate } \\
\quad 2.4 \mathrm{~mm} \text {-Glutamate }+2 \mathrm{mM} \text {-malate }\end{array}$ & $\begin{array}{l}68 \\
52 \\
72\end{array}$ & $\begin{array}{r}>90 \\
74 \\
86\end{array}$ & $\begin{array}{l}61 \\
54 \\
57\end{array}$ & $\begin{array}{l}76 \\
80 \\
94\end{array}$ \\
\hline
\end{tabular}

approx. $6 \mathrm{nmol} / \mathrm{mg}$ of protein (Clark \& Nicklas, 1970).

Effect of $\mathrm{K}^{+}$on swelling. The swelling, uptake of pyruvate, accumulation of citrate and oxygen consumption of these mitochondria in media containing $5 \mathrm{mM}-$ or $100 \mathrm{mM}-\mathrm{K}^{+}$or $-\mathrm{Na}^{+}$was investigated in several different states, since it may be suggested that the $\mathrm{K}^{+}$effects are a result of increased swelling, allowing facilitated substrate entry. Fig. 5(a) shows the low-amplitude high-energy reversible swelling (Azzone \& Azzi, 1966) that occurred in a sucrose +mannitol medium containing $100 \mathrm{~mm}-\mathrm{K}^{+}$, where the addition of substrate was necessary for a significant increase in volume. However, this swelling was completely reversed by the addition of $\mathrm{Mg}^{2+}$. Fig. 5(b) shows the same experiment except that $100 \mathrm{~mm}-\mathrm{Na}^{+}$was present instead of $\mathrm{K}^{+}$. In this case, the change in extinction was more than double that found with mitoohondria in the $\mathrm{K}^{+}$. containing medium, indicating a much greater swelling, and this was only partially reversed by $\mathrm{Mg}^{2+}$. The disappearance of pyruvate under similar conditions was also measured. Whereas the addition of $1 \mathrm{mM}-\mathrm{Mg}^{2+}$ to the mitochondria respiring in the $100 \mathrm{~mm}-\mathrm{K}^{+}$medium caused no change in the rate of disappearance of pyruvate, a similar addition in the $\mathrm{Na}^{+}$-containing medium caused an $85 \%$ decrease in utilization of pyruvate (Figs. $5 c$ and $5 d$; Table 6). However, in the above conditions, the addition of $\mathrm{Mg}^{2+}$ did not affect accumulation of citrate or oxygen uptake, both of which continued to follow linear kinetics (Table 6). In addition, the uncoupler (FCCP) caused a marked decrease in the rate of pyruvate uptake in a medium containing $5 \mathrm{~mm}$ - or $100 \mathrm{~mm}-\mathrm{K}^{+}$or $100 \mathrm{~mm}-\mathrm{Na}^{+}$, whereas the oxygen consumptions were very similar to those of state 3 .

These results suggest that swelling does occur in the high- $\mathrm{K}^{+}$medium but not as extensively as in the high- $\mathrm{Na}^{+}$medium. In both cases, partial or complete reversal of swelling could be achieved by the addition of $\mathrm{Mg}^{2+}$. However, whereas the reversal by $\mathrm{Mg}^{2+}$ of swelling in the $\mathrm{Na}^{+}$-containing medium occurred concomitantly with a shut-off of pyruvate metabolism, the reversal of swelling in the $\mathrm{K}^{+}$-containing medium did not change the rate of pyruvate oxidation.

\section{DISCUSSION}

For the purpose of discussion, one may suggest three general, but not mutually exclusive, sites at which $\mathrm{K}^{+}$might interact to cause an increase in pyruvate oxidation by rat brain mitochondria. First, $\mathrm{K}^{+}$might cause a swelling of the mitochondria and/or an associated stimulation of the electrontransport system. Secondly, $\mathrm{K}^{+}$might facilitate anion transport, in particular that of malate and pyruvate, and thirdly, $\mathrm{K}^{+}$might interact so as to stimulate the pyruvate dehydrogenase complex itself.

Swelling of rat brain mitochondria. Swelling of liver mitochondria in the presence of an increased 
Vol. 123

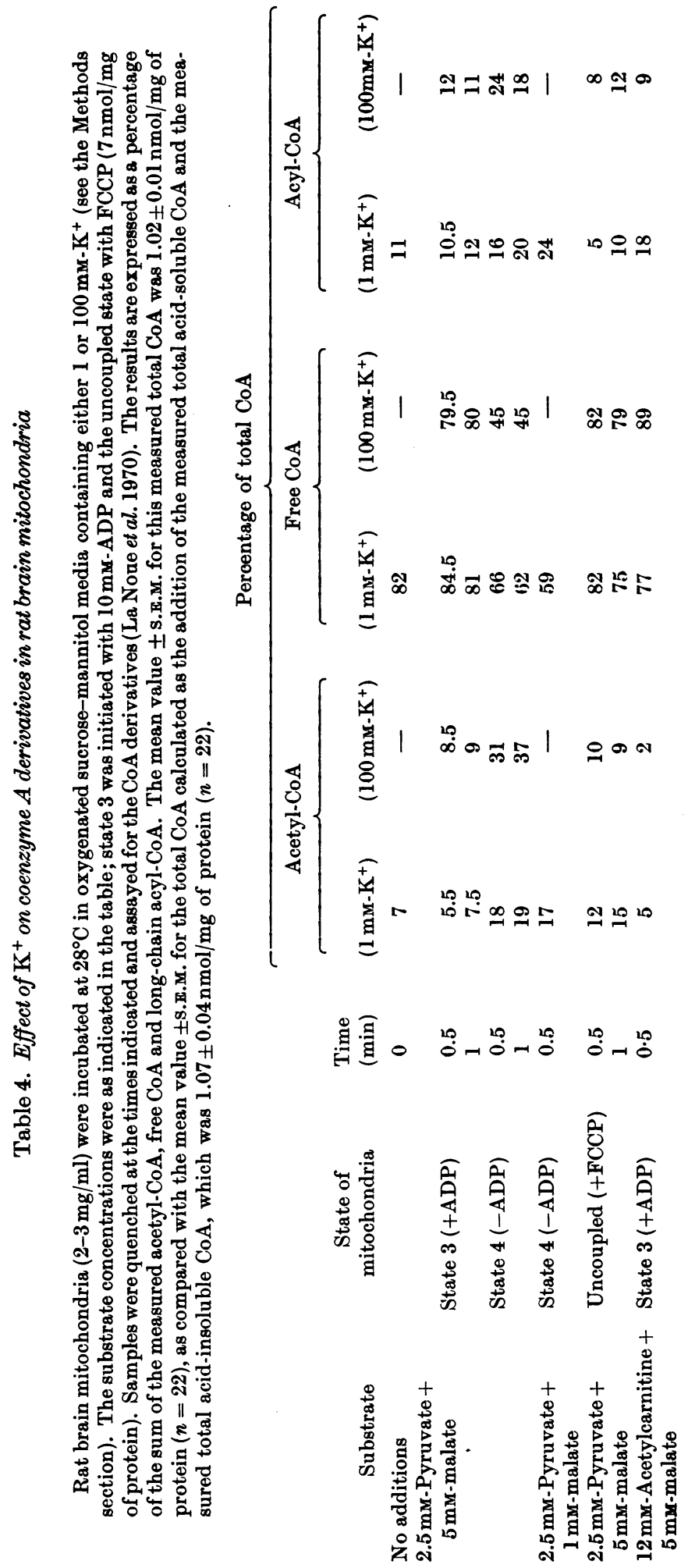




\section{Table 5. Effect of $\mathrm{K}^{+}$on $A T P$ concentrations in rat brain mitochondria}

Rat brain mitochondria (1-1.5 mg/ml) were incubated with $1 \mathrm{~mm}$-pyruvate plus $1 \mathrm{~mm}$-malate in the presence or absence of either FCCP $(7 \mathrm{nmol} / \mathrm{mg}$ of protein) or valinomycin $(7 \mathrm{ng} / \mathrm{mg}$ of protein) in media containing various concentrations of $\mathrm{K}^{+}$(see the Methods section). Samples were taken 1-5 min after initiation of reaction with mitochondria for ATP assay (see Fig. 1 for details) by methods described by Clark \& Nicklas (1970). Since there was no significant difference in samples taken at different time-intervals, these values for ATP have been pooled in this table. Results are reported \pm s.E.M., with numbers of samples in parentheses.

Concn. of ATP (nmol/mg of protein)

$\begin{array}{llccr}\text { Concn. of } \mathrm{K}^{+} \quad \text { Metabolic conditions } & \ldots & \overbrace{\text { State } 4 \text { (no ADP) }} & \text { Uncoupled } & \text { Valinomycin } \\ 5 \mathrm{mM} & & 4.10 \pm 0.03(3) & 1.22,1.41 & 2.84 \pm 0.09(4) \\ 150 \mathrm{mM} & & 4.12 \pm 0.08(3) & 1.50,1.33 & 3.05 \pm 0.14(4) \\ \text { Average over } 1-150 \mathrm{mM} & & 4.16 \pm 0.10(9) & 1.34 \pm 0.09(4)^{*} & 2.89 \pm 0.10(11)^{*}\end{array}$

* Significantly different from state $4, P<0.01$.

concentration of univalent cations is known to cause an increase in the respiration of these mitochondria and to be reversible, in certain cases, by $\mathrm{Mg}^{2+}$ (Azzone \& Azzi, 1966). Such swelling occurred with brain mitochondria (Fig. 5) in the presence of $\mathrm{K}^{+}$and, as with liver mitochondria (Azzone \& Azzi, 1966), a more pronounced swelling was observed with $\mathrm{Na}^{+}$. The small degree of swelling of brain mitochondria associated with the increase in $\mathrm{K}^{+}$concentration may well account for the slight increase in respiration and changes in the cytochrome redox states observed with acetylcarnitine (Fig. 4) or glutamate (J. B. Clark \& W. J. Nicklas, unpublished work). However, although $\mathrm{Mg}^{2+}$ reversed the mitochondrial swelling in the presence of either $100 \mathrm{~mm}-\mathrm{K}^{+}$or $100 \mathrm{~mm}-\mathrm{Na}^{+}$, pyruvate oxidation was not decreased thereby $\mathrm{i}$ then $\mathrm{K}^{+}$. containing medium but was decreased $80-90 \%$ in the $\mathrm{Na}^{+}$-containing medium (Fig. 5 and Table 6). Therefore, swelling cannot account for the enhancement of pyruvate oxidation by $\mathrm{K}^{+}$. Further, the observation that increasing $\left[\mathrm{K}^{+}\right]$from 1 to $20 \mathrm{~mm}$ caused an increase in pyruvate oxidation at the expense of glutamate (Fig. 2) furnishes additional evidence of the specific nature of $\mathrm{K}^{+}$-stimulation of pyruvate utilization in isolated brain mitochondria. This correlates well with the observations in brain slices noted previously in which $\mathbf{K}^{+}$. stimulated glycolysis at the expense of amino acids (Kini \& Quastel, 1959, 1960; Berl et al. 1968, 1970).

Facilitation of anion transport. Another possibility for the site of $\mathrm{K}^{+}$stimulation is the facilitation of transport of malate or pyruvate into the mitochondria. Harris, Hofer \& Pressman (1967) have suggested that the passage of metabolically active anions across the mitochondrial membrane is enhanced by the energy-dependent uptake of $\mathbf{K}^{+}$. Malate does not appear to be rate-limiting for pyruvate oxidation in these experiments, since the kinetics of pyruvate uptake remain linear throughout the incubation period under a variety of condi- tions (Fig. 1 and Table 1). However, the possibility of a synergistic movement of $\mathrm{K}^{+}$and malate, at low concentrations of malate or $\mathrm{K}^{+}$, consistent with the suggestion of Harris et al. (1967), cannot be excluded. The apparent $K_{\mathrm{a}}$ for malate (0.5-1 $\mathrm{mm}$ ) in these mitochondria is certainly within the range of physiological concentrations found in mammalian brain (Williamson \& Corkey, 1969; Goldberg, Passonneau \& Lowry, 1966). Goldberg et al. (1966) found that malate concentrations in mouse brain in vivo were altered by induced changes in glycolytic flux and concluded that malate concentrations may represent a valid and convenient index of tricarboxylic acid-cycle flux, i.e. an increase in malate concentration accompanied an increase in rates of glycolysis and utilization of pyruvate. Hence, both the observations in vivo and in vitro suggest that, if an increase in cytosolic malate occurred, caused by an increase in glycolysis, this in itself could facilitate the oxidation of a product of glycolysis, namely pyruvate. This suggests a possible regulatory mechanism between cytosol and mitochondria in brain where both $\mathrm{K}^{+}$concentration and availability of malate would play a role in the control of glycolysis, and a metabolic significance of the dependence of pyruvate oxidation on malate concentration.

Pyruvate dehydrogenase complex. Since there was no change in apparent $K_{m}$ for pyruvate (approx. $0.04 \mathrm{~mm}$ ) on increasing the $\mathrm{K}^{+}$concentration from 1 to $100 \mathrm{~mm}$ with the isolated intact mitochondria, and this $K_{m}$ value was similar in magnitude to values for the purified dehydrogenase from mammalian sources (Linn, Pettit, Hucko \& Reed, 1969b; Wieland, Jagow-Westermann \& Stukowski, 1969), it is difficult to conclude that entry of pyruvate could be rate-limiting, particularly as the concentration of pyruvate used in all experiments was between 0.5 and $1 \mathrm{~mm}$.

It has been shown that the acetyl-CoA/CoA and $\mathrm{NAD}^{+} / \mathrm{NADH}$ ratios may be important regulatory 


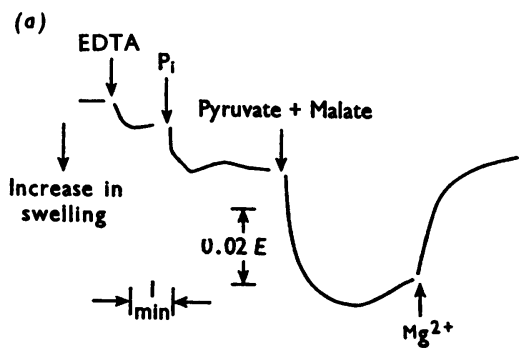

(b)
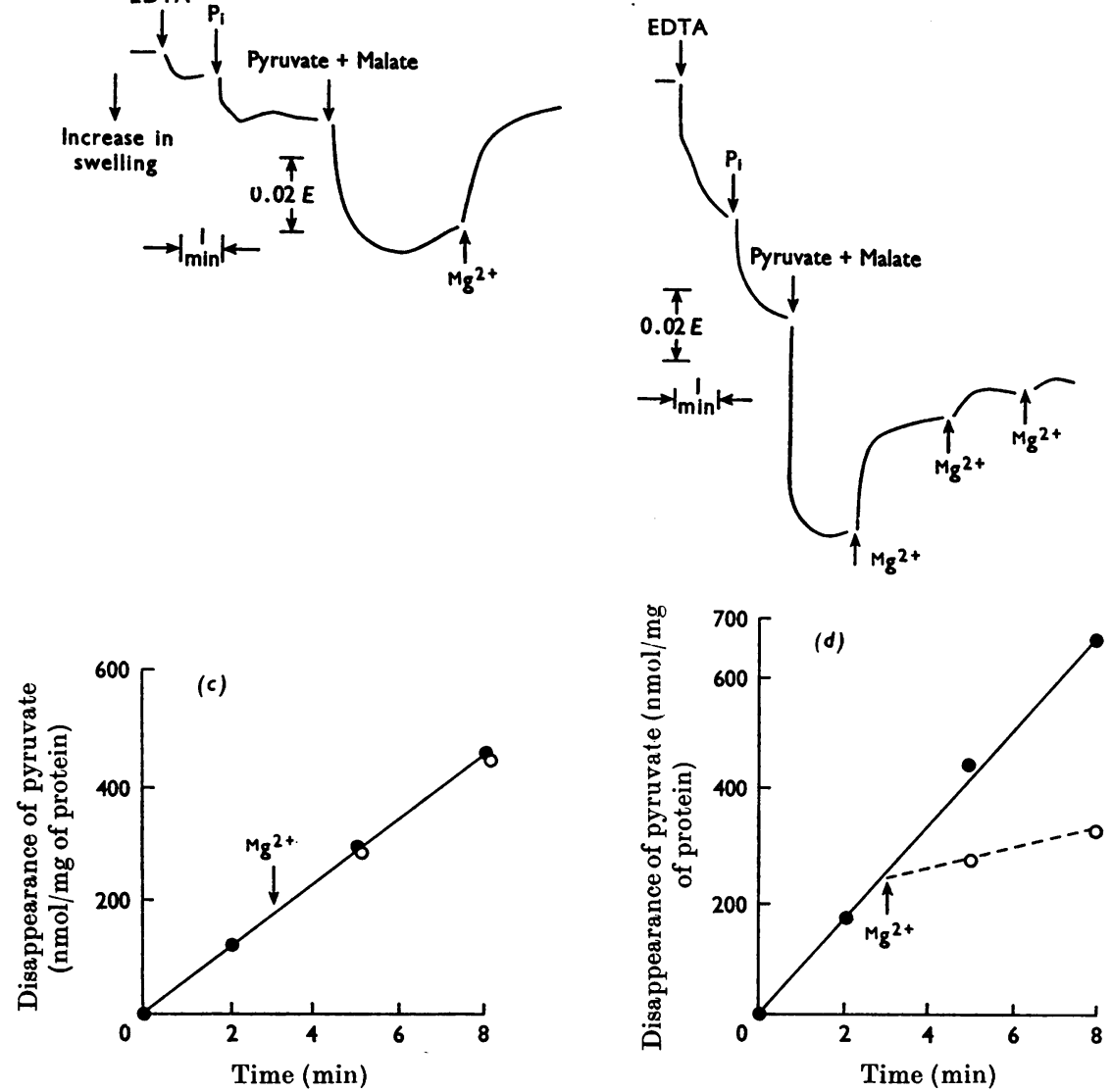

Fig. 5. Effect of $\mathrm{K}^{+}, \mathrm{Na}^{+}$and $\mathrm{Mg}^{2+}$ on the swelling and pyruvate uptake of brain mitochondria. (a) Effect of $\mathrm{K}^{+}$ on swelling of rat brain mitochondria. Rat brain mitochondria $(2.4 \mathrm{mg})$, prepared in the absence of EDTA, were suspended in a final volume of $3 \mathrm{ml}$ of a medium containing $100 \mathrm{mM}-\mathrm{K}^{+}, 75 \mathrm{mM}$-mannitol, $20 \mathrm{mM}$-sucrose, $10 \mathrm{mM}$ tris-HCl buffer, $\mathrm{pH}$ 7.4. The subsequent changes in extinction were monitored as in the Methods section. The various additions were as follows (in order of addition and final concentrations in reaction mixture): $500 \mu \mathrm{M}$ EDTA, 1 mM-P ${ }_{1}, 1$ mM-pyruvate $+2 \mathrm{mM}$-malate; $250 \mu \mathrm{M}-\mathrm{Mg}^{2+}$. (b) Effect of $\mathrm{Na}^{+}$on swelling of rat brain mitochondria. All conditions as in (a) except that the medium contained $100 \mathrm{mM}-\mathrm{Na}^{+}$in place of $\mathrm{K}^{+}$. (c) Effect of $\mathrm{Mg}^{2+}$ on disappearance of pyruvate from brain mitochondria in $100 \mathrm{mM}-\mathrm{K}^{+}$medium in state 3 . Disappearance of pyruvate (see the Methods section) was measured before and after the addition of $1 \mathrm{mM}-\mathrm{Mg}^{2+}$. $\bullet$, Control values; $O$, values after $\mathrm{Mg}^{2+}$ addition. The rate of disappearance of pyruvate both before and after addition of $\mathrm{Mg}^{2+}$ was $58 \mathrm{nmol} / \mathrm{min}$ per $\mathrm{mg}$ of protein. (d) Effect of $\mathrm{Mg}^{2+}$ on disappearance of pyruvate from brain mitochondria in state 3 in $100 \mathrm{~mm}-\mathrm{Na}^{+}$medium. The experiment was identical with that in (c) except that the medium contained $100 \mathrm{mM}-\mathrm{Na}^{+}$instead of $\mathrm{K}^{+}$. The rate of disappearance of pyruvate before and after $\mathrm{Mg}^{2+}$ addition was 93 and $10 \mathrm{nmol} / \mathrm{min}$ per $\mathrm{mg}$ of protein respectively.

factors for pyruvate dehydrogenase activity (Garland \& Randle, 1964; Hansen \& Henning, 1966). Since there was no change in nicotinamide nucleotide reduction in mitochondria respiring in state 3 in media containing either 5 or $100 \mathrm{~mm}-\mathrm{K}^{+}$ (Table 3), the mode of action of $\mathrm{K}^{+}$is not to alleviate an inhibition of pyruvate dehydrogenase by NADH. Similarly, if $\mathrm{K}^{+}$acted to relieve an inhibition of pyruvate oxidation caused by an accumulation of
acetyl-CoA, there should have been a decrease in acetyl-CoA on increasing the concentration of $\mathrm{K}^{+}$. This did not occur and in fact, in both states 3 and 4, acetyl-CoA increased (Table 4). The increase in acetyl-CoA caused by $\mathrm{K}^{+}$occurred simultaneously with increased pyruvate utilization and flux through acetyl-CoA, indicating a stimulation of the net formation of acetyl-CoA from pyruvate.

One other possibility remains, that $\mathrm{K}^{+}$caused an 
Table 6. Comparison of the effects of $\mathrm{K}^{+}, \mathrm{Na}^{+}$and $\mathrm{Mg}^{2+}$ on the oxidation of pyruvate by rat brain mitochondria

Rat brain mitochondria were incubated at $28^{\circ} \mathrm{C}$ either in the 'zero' medium or in media containing $100 \mathrm{mM}^{-\mathrm{K}^{+}}$ or $-\mathrm{Na}^{+}$(see the Methods section). Substrate used was $1 \mathrm{~mm}$-pyruvate-5 mM-malate and respiration was stimulated by the addition of $10 \mathrm{mM}$-ADP (disodium salt) or FCCP ( $7 \mathrm{nmol} / \mathrm{mg}$ of protein). Compensation was made for the $\mathrm{Na}^{+}$added with ADP (approx. $20 \mathrm{~mm}-\mathrm{Na}^{+}$). In some cases $1 \mathrm{mM}-\mathrm{Mg}^{2+}$ was added part way through the incubation as outlined in Figs. $5(c)$ and $5(d)$. Metabolite and oxygen changes were measured as described in Figs. 1 and 2. The results expressed here and in Figs. $5(c)$ and $5(d)$ are for the same mitochondrial preparation.

\begin{tabular}{|c|c|c|c|c|}
\hline Medium & Additions & $\begin{array}{l}\text { Disappearance } \\
\text { of pyruvate } \\
\text { (nmol/min per } \mathrm{mg} \\
\text { of protein) }\end{array}$ & $\begin{array}{c}\text { Accumulation } \\
\text { of citrate } \\
\text { (nmol/min per } \mathrm{mg} \\
\text { of protein) }\end{array}$ & $\begin{array}{c}\text { Uptake of oxygen } \\
\text { (ng-atoms/min per mg } \\
\text { of protein) }\end{array}$ \\
\hline $0 \mathrm{Na}^{+}, \mathrm{K}^{+}$ & $\begin{array}{l}+\mathrm{ADP} \\
+\mathrm{FCCP}\end{array}$ & $\begin{array}{l}32 \\
13\end{array}$ & $\begin{array}{l}3.7 \\
9\end{array}$ & $\begin{array}{l}84 \\
84\end{array}$ \\
\hline $100 \mathrm{~mm}-\mathrm{Na}^{+}$ & $\begin{array}{l}+ \text { ADP } \\
\text { +FCCP }\end{array}$ & $\begin{array}{l}93 \\
44.5\end{array}$ & $\begin{array}{r}8 \\
18\end{array}$ & $\begin{array}{l}229 \\
201\end{array}$ \\
\hline $100 \mathrm{~mm}-\mathrm{Na}^{+}$ & $\begin{array}{l}+1 \mathrm{mM}-\mathrm{Mg}^{2+} \\
\quad+\mathrm{ADP}\end{array}$ & 10 & 5.5 & 229 \\
\hline $100 \mathrm{mM}-\mathrm{K}^{+}$ & $\begin{array}{l}+\mathrm{ADP} \\
+\mathrm{FCCP}\end{array}$ & $\begin{array}{l}58 \\
21.5\end{array}$ & 12 & $\begin{array}{l}177 \\
204\end{array}$ \\
\hline $100 \mathrm{~mm}-\mathrm{K}^{+}$ & $\begin{array}{l}+1 \mathrm{mM}-\mathrm{Mg}^{2+} \\
+\mathrm{ADP}\end{array}$ & 58 & 5.5 & 177 \\
\hline
\end{tabular}

activation of the pyruvate dehydrogenase complex itself. Recent investigations in several laboratories have shown that the pyruvate dehydrogenase complex exists in two forms, an inactivated phosphorylated form and an activated dephosphorylated form in ox kidney (Linn, Pettit \& Reed, 1969a), ox heart, pig liver (Linn et al. 1969b) and pig heart (Wieland et al. 1969; Wieland \& Siess, 1970). The overall activity of the enzyme complex is established by regulating the relative activities of the inactivating ATP-dependent kinase and the activating phosphatase. Several factors control the activity of these activating/deactivating enzymes. Both are $\mathrm{Mg}^{2+}$-dependent (Linn et al. 1969a; Wieland \& Siess, 1970), but the inactivating kinase is active at low $\mathrm{Mg}^{2+}$ concentrations, whereas the activating phosphatase requires high $\mathrm{Mg}^{2+}$ concentrations (10 mM). Further, the activating phosphatase is stimulated by cyclic AMP. Although Sattin \& Rall (1967) have reported increased cyclic AMP concentrations in guinea-pig brain slices on increasing the $\mathrm{K}^{+}$concentration in the medium, this does not appear to be mechanism of the $\mathrm{K}^{+}$-stimulation, since the addition of cyclic AMP to rat brain mitochondria respiring in the presence of ADP in low- $\mathrm{K}^{+}$ medium does not cause any increase in disappearance of pyruvate (J. B. Clark \& W. J. Nicklas, unpublished work). It seems more probable that $\mathrm{K}^{+}$ may affect the $\mathrm{Mg}^{2+}$ requirements of the brain pyruvate dehydrogenase complex. Further investigations with the isolated brain complex are required to establish this point.

Physiological significance of $\mathrm{K}^{+}$-stimulated re- spiration. The concentrations of $\mathrm{K}^{+}$and $\mathrm{Na}^{+}$in brain differ greatly from those in the plasma. The concentrations of these electrolytes in rat plasma are $4 \mathrm{~mm}-\mathrm{K}^{+}$and $140 \mathrm{~mm}-\mathrm{Na}^{+}$; in rat brain, $100 \mathrm{~mm}-\mathrm{K}^{+}$ and $50 \mathrm{~mm}-\mathrm{Na}^{+}$(Long, 1961). Thus, the high concentration of $\mathrm{K}^{+}$used in these experiments approximates to the values in vivo. The enhancement of pyruvate oxidation observed on increasing $\mathrm{K}^{+}$to $100 \mathrm{~mm}$ may therefore reflect a return to the normal ionic environment in vivo whereby oxidation of pyruvate and cytosolic NADH are maintained at maximal and constant rates. This is in line with the role of glycolysis as the principal energy source in brain and the necessity for providing a continuous and relatively high degree of energy production.

If a more specific regulatory role for $\mathrm{K}^{+}$in brain is suggested (i.e. a change in $\mathrm{K}^{+}$concentration causing an alteration in metabolism), it is necessary to invoke microcompartments in which extreme differences in $\mathrm{K}^{+}$concentration can occur. The suggestion that neuroglial cells buffer the extracellular space around neurons and presynaptic terminals against increases in $\mathrm{K}^{+}$may argue for such localized $\mathrm{K}^{+}$'sinks' (Trachtenberg \& Pollen, 1970; Pollen \& Trachtenberg, 1970). In such cases, uptake of $\mathrm{K}^{+}$from the extraglial compartment, particularly immediately after neuronal discharge, may well have important regulatory functions. It will be interesting to discover whether mitochondria prepared from neuronal cells have a response to $\mathrm{K}^{+}$ different from that observed with glial mitochondria. 
We thank Dr Angelo Azzi of Padova University, Italy, for enlightening discussions about mitochondrial swelling. In addition, the excellent technical assistance of Mrs Ilga Wohlrab and Mrs Mary Moore is gratefully acknowledged. W.J.N. thanks the National Institutes of Health for a postdoctoral fellowship (1968-1970) and J.B.C. the Medical Research Council for a Travelling Fellowship while on leave of absence from the Biochemistry Department, St Bartholomew's Hospital Medical College, University of London. J.R. W. is an Established Investigator of the American Heart Association. This work was supported by grants from the U.S. Public Health Service (GM 12202).

\section{REFERENCES}

Ashford, C. A. \& Dixon, K. C. (1935). Biochem. J. 29, 157.

Azzone, G. F. \& Azzi, A. (1966). In Regulation of Metabolic Processes in Mitochondria, p. 332. Ed. by Tager, J. M., Papa, S., Quagliariello, E. \& Slater, E. C. New York: Elsevier Publishing Co.

Balazs, R. (1965). Biochem. J. 95, 497.

Berl, S., Nicklas, W. J. \& Clarke, D. D. (1968). J. Neurochem. 15, 131.

Berl, S., Nicklas, W. J. \& Clarke, D. D. (1970). J. Neurochem. 17, 1009.

Chance, B. \& Williams G. R. (1956). Adv. Enzymol. 17, 65.

Clark, J. B. (1970). Fedn Proc. Fedn Am. Socs exp. Biol. 29, 471Abstr.

Clark, J. B. \& Nicklas, W. J. (1970). J. biol. Chem. 245, 4724.

De Robertis, E., Rodriguez de Lores Arnaiz, G., Alberici, M., Butcher, R. W., \& Sutherland, E. W. (1967). J. biol. Chem. 242, 3487.

Dickens, F. \& Greville, G. D. (1935). Biochem. J. 29, 1468.

Elliott, K. A. C. \& Wolfe, L. S. (1962). In Neurochemistry, 2nd ed., p. 182. Ed. by Elliott, K. A. C., Page, I. H. \& Quastel, J. H. Springfield, Ill.: Charles C. Thomas.

Garland, P. B. \& Randle, P. J. (1964). Biochem. J. 91, $6 \mathrm{c.}$

Goldberg, N. D., Passonneau, J. V. \& Lowry, O. H. (1966). J. biol. Chem. $241,3997$.
Hanig, R. C. \& Aprison, M. M. (1967). Analyt. Biochem. $21,169$.

Hansen, R. G. \& Henning, U. (1966). Biochim. biophys. Acta, 122, 352.

Harris, E. J., Hofer, M. P. \& Pressman, B. C. (1967). Biochemistry, Easton, 6, 1348.

Kimmich, G. A. \& Rasmussen, H. (1967). Biochim. biophys. Acta, 131, 413.

Kini, M. M. \& Quastel, J. H. (1959). Nature, Lond., 184, 252.

Kini, M. M. \& Quastel, J. H. (1960). Science, N.Y., 131, 412.

Krall, A. R., Wagner, M. C. \& Gozansky, D. M. (1964). Biochem. biophys. Res. Commun. 16, 77.

La Noue, K., Nicklas, W. J. \& Williamson, J. R. (1970). J. biol. Chem. 245, 102.

Linn, T. C., Pettit, F. H., Hucko, F. \& Reed, L. J. (1969b). Proc. natn. Acad. Sci. U.S.A. 64, 227.

Linn, T. C., Pettit, F. H. \& Reed, L. J. (1969a). Proc. natn. Acad. Sci. U.S.A. 62, 234.

Long, C. (1961). Biochemists' Handbook, p. 642. London: D. Van Nostrand.

Moore, C. \& Pressman, B. C. (1964). Biochem. biophys. Res. Commun. 15, 562.

Ozawa, K., Seta, K., Araki, H. \& Handa, H. (1967). J. Biochem., Tokyo, 61, 352.

Pollen, D. A. \& Trachtenberg, M. (1970). Science, N.Y., 167, 1252.

Quastel, J. H. (1962). In Neurochemistry, 2nd ed., p. 226. Ed. by Elliott, K. A. C., Page, I. H. \& Quastel, J. H. Springfield, Ill.: Charles C. Thomas.

Sattin, A. \& Rall, T. W. (1967). Fedn Proc. Fedn Am.Socs exp. Biol. 26, 707 Abstr.

Trachtenberg, M. \& Pollen, D. A. (1970). Science, N.Y., $167,1248$.

Utida, S. \& Sugawara, H. (1963). J. Biochem., Tokyo, 54, 553.

Wieland, O., Jagow-Westermann, B. \& Stukowski, B. (1969). Hoppe-Seyler's Z. physiol. Chem., 350, 329.

Wieland, O. \& Siess, E. (1970). Proc. natn. Acad. Sci. U.S.A. 65, 947.

Williamson, J. R. \& Corkey, B. E. (1969). In Methods in Enzymology, vol. 13, p. 434. Ed. by Lowenstein, J. M. New York: Academic Press Inc.

Williamson, J. R., Fukami, M. H., Peterson, M. J., Rostand, S. G. \& Scholz, R. (1969). Biochem. biophys. Res. Commun. 36, 407. 